\title{
2 次元および軸対称選択取水に関する研究 STUDY ON TWO DIMENSIONAL AND AXISYMMETRIC SELECTIVE WITHDRAWAL
}

\author{
吉川秀 夫*・山田 正**・水谷俊孝*** \\ By Hideo KIKKAWA, Tadashi YAMADA and Toshitaka MIZUTANI
}

\section{1. 序論}

密度成層をした 流体の挙動は非常に 複雑であり, ま た，その運動形態も予期しないものがあり，実験室内規 模のスケールの運動から大気, 大洋の規模のスケールの 運動までわれわ机を上りまく空気，水の運動は多かれ少 なか机密度成層の影響を受けている。一方, 密度成層の 流れに与える効果を積極的に利用したものの1つとして ダム貯水池の放水 (取水), あるいは火力および原子力 発電の冷却用水の取水等に行われる選択取水 (selective withdrawal) がある. 貯水池においては洪水時に貯水 池に入った濁度の高い水塊は長期間滞留し, 洪水が終っ た後も放流水が濁る長期濁水放流の問題が生じたり, 冷 水放流にともなう農業用水の冷化等の問題が発生する. また，火力および原子力発電所においては，冷却用水と して多量の低温水を必要とするため一般に取水口は底近 くに設けられる場合が多いが，あまり底近くに設置する と底面近くの濁度の高い水を吸い込む恐れがあり.また， これを避けるために水表面近くに設置すると温度の高い 水を取水することになり泠却の効率を落としたり，クラ ゲ等の海洋生物を吸入する問題が発生する。いずれの問 題においても結局, 取水（放流）時にいかにして最適の 水を他の箇所に支障なく必要量を確保し得るかが選択取 水の問題といえよう.

一般にダム眝水池に执いては眝水池内に円筒形の取水 塔を設け, 水道水等を取水していたり, また, ダム本体 に発電用取水口劣るいは放水口を設けている例が多い ようである.これらの取水形式では流れの場は取水塔

（口）まわりに軸対称になると思われる，一方，火力あ るいは原子力発電所の復水器泠却用に使われる冷却水の

* 正会員 I博 東京工業大学教授 【学部土木工学科

** 正会員 工修 東京上業大学助手 1学部土杠学科

***学生会員 東京了:業大学大学院
取水方法にはカーテンウォール式取水と海底取水管式に 大別され，カーテンウォール式も平面形状を円弧形にす ると, これらの取水口への流れは軸対称になることが報 告されている ${ }^{16)}$.

一方, これらの流れの理論的解析や実験を行らにあた っては 2 次元取水の問題を取り扱う方がより簡単であ る.よって本論文では 2 次元取水ならびに軸対称取水の 両者の理論的解析を行い, これらの流れの相違を調べて みることにより選択取水の物理的内容をより明確にし, さらに 2 次元取水に関して行った実験結果について述べ ている.ところで本研究で扱っているのはある時刻から 階段関数 (step function) 的に一定流量を取水し始める いわゆる過渡応答の問題を考えているが，取水前の時刻 では貯水池内は静榣で, 水は止まっており, 取水前の密 度分布としては水面から水底まで密度が直線的に変化す る場を考えている. しかしながら，吉川・山本 ${ }^{3)}$ の研究 によると, 実際のダム貯水池の温度分布は夏季には表層 近くと放流口高さ近くに 2 つの温度躍層をもっており, 深層温度躍層面が放流口高さに安定に形成され, 大洪水 が起きた場合以外はくずれることがないことを報告して おり，石橋・秋本ら ${ }^{20)}$ も同様の報告をしている，このよ うに本研究で扱っている密度分布と実際の貯水池等で生 ビているものとは必ずしも同じではないが，選択取水の 問題の解析にあたっては密度分布が直線の場合がもっと も基本的と思われることにより以下の研究を行った. と ころで成層流体の流れを支配しているパラメーターの 1 つに後に定義する取水流量と密度勾配からなる内部フル 一ド数 $F_{r}$ があるが, 従来からの研究により $F_{r}$ が 1 よ り小さいある值以下になると取水口上下によどみ層がで きることが知られており，このときがいわゆる選択取水 の状態になっている. よって本研究で取り扱う内部フル 一ド数も 1 以下の十分に小さい場合を考えることにす る. 著者らはこの問題に関し 2 次元取水の場合の線形理 論解を出している ${ }^{21}$. よって本論文はこの研究 (以後こ 
れを論文 I とよぶ）をふまえ，2次元取水ならびに軸対 称取水の理論展開を行い, さらに両者の比較検討を行っ たものである。

\section{2. 従来の研究}

密度成層をしたダム貯水池や海からの選択取水の問題 の取り扱いにおいては成層の状態によって密度の異なる 2 成層流体からの取水の場合と, 連続成層流体からの取 水の場合とがあり前者については取水方式（上層取水, 下層取水のそれぞれにつき，上下横方向取水等がある） ごとに理論解析がなされ，十分な精度で実験を説明し得 ることが報告されている ${ }^{1)}$. 一方, 連続成層の場合には, Debler $^{2)}$ の実験的研究や, Yih ${ }^{4}$ の解析的研究以来今 日まで数多くの研究がなされており，以下にそれらを簡 単に review してみる。 まず Debler の実験は鉛直方 向の密度分布を直線とし，2次元水槽の一方の側に line sink を設けてこれより一定流量を 取水するものである が，内部フルード数 $F_{r}$ がある 臨界值（彼の実験では $\left.F_{r}=0.28\right)$ 以下になると取水口上層部に 静止領域（よ どみ層) が生じることを見い出した．これに対し Yih は Debler の実験とほぼ同一条件のもとでの理論解析 を行い, よどみ層のできる臨界フルード数が $F_{r}=1 / \pi$ となる結果を得た. しかし，彼の得た解では $F_{r}$ が $1 / \pi$ より小さくなると上流端の境界条件を破壊してしまい, 十分上流では一様流速になるという境界条件とは別の取 り扱いをしなければならないことがわかっている。この Yih の解を改良したものに $\mathrm{Kao}^{6), 7)}$ の解があり，側端 に仮想の $\operatorname{sink}$ を新たに導入することにより，Yih の解 の破綻を避けている。しかし，これは一種の技法であ り，本質的に問題が解決したわけではない，さらに取水 流量が極端に小さい場合 (creeping flow) について $\mathrm{Koh}^{11)}$ の研究があり, 密度の拡散も考虑し, 境界層型 の近似と, 相似変換の手法による解が得られており, 実 験とのよい一致をみている.しかしながら, Imberger ${ }^{13)}$ によるとこの解は，鉛直断面をよぎる体積フラックスは 保存されていても運動量が保存されていないことが明ら かにされており, 彼は新たに貯水池の有限性を考慮に入 れた議論を行っている. 一方, $\mathrm{PaO}$ and $\mathrm{Kao}^{9), 10)}$ はこ れらの事情をふまえて非定常問題として選択取水の問題 を取り扱い，解析および数值計算を行うことにより，密 度成層流体からの取水時には特異な波動が存在すること を明らかにした．また，彼らの計算によりたとえ内部フ ルード数が小さい流れでも運動方程式中の非線形項は無 視し得るほどは小さくないことを示している．これらの 研究にさきがけ Trustrum ${ }^{5)}$ は運動方程式中の移流項を 部分的に残した Oseèn 近似に基づき，非定常問題とし
ての選択取水の解を得ている. しかし, 彼女の得た定常 解には前述の波動性が十分に考慮されていなかった．著 者ら ${ }^{21)}$ はこの点を考虑し, さらに粘性の効果をも加味し た 2 次元選択取水の線形理論解を出している. 既述の論 文Iにおいて, 粘性の効果を示すレイノルズ数を適当に 選ぶならば実験で得られる流速分布等はかなりの程度ま で説明されることが示されている. 一方, これらの研究 で取り扱っている line sink の 2 次元取水と違った軸対 称取水に関して, 日野・大西 ${ }^{14) ~(16)}$ の一連の研究があり, 選択取水に及ぼす取水口の高さの効果が議論されてい る. また, $\mathrm{Koh}^{12)}$ は軸対称取水の非定常問題を扱って いる. これらの研究をふまえ, 本論文は, 文献 9) がお もに数值計算によって選択取水の問題を取り扱っている のに対し，モードをもった各波動の伝播という点に着目 して, この現象をより明確にするために, 非定常問題と しての解析的研究を行い，2次元ならびに軸対称取水の 再者を一括して議論したものである.

\section{3. 理 論}

\section{（1）基礎方程式}

上記のように 2 次元取水と軸対称取水を統一的に論じ るために流れの場の座標系を図一1に示す. 図中の $\xi_{0}$, $x_{0}$ は取水塔半径, あるいは取水塔位置である.

基礎方程式としては Euler の連続の式（密度の拡散 は考慮しない)

$$
\frac{\partial \rho}{\partial t}+\operatorname{div}(\rho \boldsymbol{v}) \equiv \frac{d \rho}{d t}+\rho \operatorname{div}(\boldsymbol{v})=0 \cdots
$$

ここに, $\rho$ 滵度, $v$ は速度べクトルを表している. 次 に流体粒子の密度が時間の経過に従って変化しない，い わゆる非圧縮の条件は,

$$
\frac{d \rho}{d t}=\frac{\partial \rho}{\partial t}+u \frac{\partial \rho}{\partial r}+w \frac{\partial \rho}{\partial z}=0 .
$$

式 (1), (2) より, $\operatorname{div}(\boldsymbol{v})=0$

運動の方程式としては, 重力加速度 $g$ にかかった密 度 $\rho$ 以外のすべての密度を reference density $\rho_{0}$ とす るいわゆる Bousinessq 近似を用いた Euler の運動方

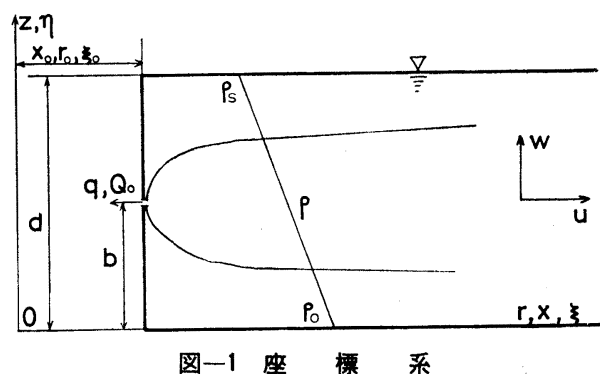


程式を考える.

$r$ 一方向 : $\frac{\partial u}{\partial t}+u \frac{\partial u}{\partial r}+w \frac{\partial u}{\partial z}=-\frac{1}{\rho_{0}} \frac{\partial P}{\partial r}$

$z$-方向 : $\frac{\partial w}{\partial t}+u \frac{\partial w}{\partial r}+w \frac{\partial w}{\partial z}=-\frac{1}{\rho_{0}} \frac{\partial P}{\partial z}$

$$
-\frac{\rho}{\rho_{0}} g
$$

ここで，末知数は $u, w, P, \rho$ の 4 個であり，構成式は 式 (2)，(4)，(5) の 3 本である. 次に式 (4)，(5)より cross-differential を取り, 圧力 $P$ を消去する.

$$
\frac{\partial \omega}{\partial t}+u \frac{\partial \omega}{\partial r}+w \frac{\partial \omega}{\partial z}-\frac{u}{r} \omega=\frac{g}{\rho_{0}} \frac{\partial \rho}{\partial r} \cdots(6)
$$

ここに, $\omega=\partial u / \partial z-\partial w / \partial r$ で定義される渦度である.

次に Stokes の流れの関数 $\phi$ を導入する.

$$
\left.\begin{array}{l}
u=\frac{1}{r} \frac{\partial \phi}{\partial z}, w=-\frac{1}{r} \frac{\partial \psi}{\partial r} \\
\omega=\nabla^{2} \phi \\
\nabla^{2}=\frac{1}{r}\left[\frac{\partial^{2}}{\partial z^{2}}+\frac{\partial^{2}}{\partial r^{2}}-\frac{1}{r} \frac{\partial}{\partial r}\right]
\end{array}\right\}
$$

式（7）で定義される流れの関数を式 (2)，(6) に用い ると,

$$
\begin{array}{r}
\frac{\partial \rho}{\partial t}+\frac{1}{r} \frac{\partial \psi}{\partial z} \frac{\partial \rho}{\partial r}-\frac{1}{r} \frac{\partial \psi}{\partial r} \frac{\partial \rho}{\partial z}=0 \ldots \ldots . . \\
\frac{\partial}{\partial t} \nabla^{2} \phi+\frac{1}{r} \frac{\partial \psi}{\partial z} \frac{\partial}{\partial r} \nabla^{2} \psi-\frac{1}{r} \frac{\partial \psi}{\partial r} \frac{\partial}{\partial z} \nabla^{2} \psi \\
-\frac{1}{r^{2}} \frac{\partial \psi}{\partial z} \nabla^{2} \psi=\frac{g}{\rho_{0}} \frac{\partial \rho}{\partial r} \quad \cdots \cdots \cdots \cdots
\end{array}
$$

ここで，取水を開始する前の密度分布は既述のように直 線分布とすると, $t>0$ つまり取水開始後の密度 $\rho$ は, 次のように表すことができる.

$$
\rho(r, z, t)=\rho_{0}(1-\varepsilon z)+\rho^{\prime}(r, z, t)
$$

ここに, $\varepsilon=\left(\rho_{0}-\rho_{s}\right) / \rho_{0} d, \rho_{0}, \rho_{s}$ はそれぞれ $z=0, d$ で の密度である。

式（10）を式 (8),(9) に代入して,

$$
\begin{aligned}
& \frac{\partial \rho^{\prime}}{\partial t}+\frac{1}{r} \frac{\partial \psi}{\partial z} \frac{\partial \rho^{\prime}}{\partial r}-\frac{1}{r} \frac{\partial \psi}{\partial r}\left(-\varepsilon \rho_{0}+\frac{\partial \rho^{\prime}}{\partial z}\right)=0 \\
& \frac{\partial}{\partial t} \nabla^{2} \phi+\frac{1}{r} \frac{\partial \psi}{\partial z} \frac{\partial}{\partial r} \nabla^{2} \phi-\frac{1}{r} \frac{\partial \psi}{\partial r} \frac{\partial}{\partial z} \nabla^{2} \psi \\
& -\frac{1}{r^{2}} \frac{\partial \psi}{\partial z} \nabla^{2} \phi=\frac{g}{\rho_{0}} \frac{\partial \rho^{\prime}}{\partial r}
\end{aligned}
$$

以下の理論展開においては, 式 (11)，(12) をもとに未 知数 $\rho^{\prime}, \phi$ を求める.

\section{(2) 無次元化}

基本式の無次元化にあたって長さの規準としては水 深 $d$, 時間は密度成層の勾配 $\varepsilon$ から決まる時間スケール $T$ (Brunt-Väisälä 振動数の逆数), 流れの関数は取水流 量 $Q_{0}$, , 密度は底面密度 $\rho_{0}$ を用いて行うと,

$$
\left\{\begin{array}{l}
\xi=r / d, \eta=z / d, \tau=t / T, T=1 / \sqrt{\varepsilon g} \\
\varphi=\phi /\left(Q_{0} / 2 \pi\right), \quad \zeta=\rho / \rho_{0} \beta, \beta=\left(Q_{0} / d^{2}\right) / 2 \pi g^{\prime} T \\
G=Q_{0} T / 2 \pi d^{3}=Q_{0} / 2 \pi d^{3} \sqrt{\varepsilon g}\left(\text { 日野.大西 }{ }^{14)} \sim 16\right) \\
\text { の研究において用いられている取水パラメータ } \\
\text { 一で一種の内部フルード数 })
\end{array}\right.
$$

となり, 式 (11), (12) は,

$$
\begin{aligned}
& \frac{\partial}{\partial \tau} \nabla^{2} \varphi+G \frac{1}{\xi} \frac{\partial\left(\nabla^{2} \varphi, \varphi\right)}{\partial(\xi, \eta)}-G \frac{1}{\xi^{2}} \frac{\partial \varphi}{\partial \eta} \nabla^{2} \varphi \\
& =\frac{\partial \zeta}{\partial \xi} \\
& \frac{\partial \zeta}{\partial \tau}+G \frac{1}{\xi} \frac{\partial(\varphi, \zeta)}{\partial(\eta, \xi)}+\frac{1}{\xi} \frac{\partial \varphi}{\partial \xi}=0
\end{aligned}
$$

以後は式（13)，(14）をもとにして議論する.

\section{（3） 摂動法による解}

本研究では取水パラメーターとしての $G$ が 1 に比べ 十分小さい場合を取り扱うことにより， $\varphi$ と $\zeta$ を $G$ に 関して次のように展開する。

$$
\left.\begin{array}{l}
\varphi=\varphi_{0}+G \varphi_{1}+G^{2} \varphi_{2}+\cdots \\
\zeta=\zeta_{0}+G \zeta_{1}+G^{2} \zeta_{2}+\cdots
\end{array}\right\}
$$

式（15）を式 (13)，(14) に代入し，第0近似のみをと ると,

$$
\begin{aligned}
& \frac{\partial}{\partial \tau} V^{2} \varphi_{0}=\frac{\partial \zeta_{0}}{\partial \xi} \cdots \\
& \frac{\partial \zeta_{0}}{\partial \tau}+\frac{1}{\xi} \frac{\partial \varphi_{0}}{\partial \xi}=0
\end{aligned}
$$

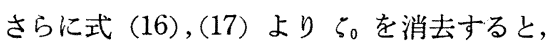

$$
\frac{\partial^{2}}{\partial \tau^{2}} \nabla^{2} \varphi_{0}-\frac{1}{\xi^{2}} \frac{\partial \varphi_{0}}{\partial \xi}+\frac{1}{\xi} \frac{\partial^{2} \varphi_{0}}{\partial \xi^{2}}=0
$$

式（18）の両辺に $\xi$ をかける ,

$$
\begin{aligned}
& \frac{\partial^{2}}{\partial \tau^{2}}\left\{\frac{\partial^{2}}{\partial \eta^{2}}+\frac{\partial^{2}}{\partial \xi^{2}}-\frac{1}{\xi} \frac{\partial}{\partial \xi}\right\} \varphi_{0}-\frac{1}{\xi} \frac{\partial \varphi_{0}}{\partial \xi} \\
& +\frac{\partial^{2} \varphi_{0}}{\partial \xi^{2}}=0
\end{aligned}
$$

ここで, 式 (19) の解を次式のようにおくと,

$$
\varphi_{0}=-\eta H(\tau)+\varphi_{*}(\xi,\lceil\eta, \boldsymbol{\Gamma} \tau)
$$

ここに, $H(\tau)$ : 単位段階関数 (unit step function) 式（20）を式（19）に代入して,

$$
\begin{aligned}
& \frac{\partial^{2}}{\partial \tau^{2}}\left\{\frac{\partial^{2}}{\partial \eta^{2}}+\frac{\partial^{2}}{\partial \xi^{2}}-\frac{1}{\xi} \frac{\partial}{\partial \xi}\right\} \varphi_{*}-\frac{1}{\xi} \frac{\partial \varphi_{*}}{\partial \xi} \\
& +\frac{\partial^{2} \partial_{*}}{\partial \xi^{2}}=0
\end{aligned}
$$

式（21）が軸対称取水の解くべき式となる.

\section{（4） $\varphi_{0}$ および $\varphi_{*}$ に対する境界条件}

$\varphi_{0}$ に対しては,
(i) $\varphi_{0}=-H(\tau)$
$\xi_{0} \leq \xi<\infty, \eta=1$
(ii) $\varphi_{0}=0$
$\xi_{0} \leq \xi<\infty, \eta=0$
(iii) $\varphi_{0}=-\eta H(\tau) \quad \xi \rightarrow \infty, 0 \leq \eta \leq 1 \quad(\tau \ll \infty)$ 
(iv) $\varphi_{0}=\left\{\begin{array}{cc}0 & 0 \leq \eta \leq b \\ -H(\tau) & b \leq \eta \leq 1\end{array}\right\} \xi=\xi_{0}$

(v) $\partial / \partial \tau\left(\nabla^{2} \varphi_{0}\right)=\partial \zeta / \partial \xi=0 \quad \tau<0$

(取水開始前に半径方向に密度変化はない)

(vi) $\nabla^{2} \varphi_{0}=0 \tau<0$ (取水開始前には渦度はない)

$\varphi_{*}$ に対して境界条件を考えると，

(i ) $\varphi_{*}=0 \quad \xi_{0} \leq \xi<\infty, \eta=1$

(ii) $\varphi_{*}=0 \quad \xi_{0} \leq \xi<\infty, \eta=0$

(iii) $\varphi_{*}=0 \quad 0 \leq \eta \leq 1, \xi \rightarrow \infty$

(iv) $\varphi_{*}\left(\xi_{0}\right)=-F(\tau, \eta)+\eta H(\tau) \quad 0 \leq \eta \leq 1, \xi=\xi_{0}$

$$
\text { ここに } F(\tau, \eta)=\left\{\begin{array}{cc}
0 & 0 \leq \eta \leq b \\
H(\tau) & b \leq \eta \leq 1
\end{array}\right.
$$

$\left.\begin{array}{l}\text { (v) } \partial / \partial \tau\left(\nabla^{2} \varphi_{*}\right)=\partial \zeta / \partial \xi=0 \\ \text { (vi) } \nabla^{2} \varphi_{*}=0\end{array}\right\} \tau<0$

\section{（5） 2 次元選択取水}

式（21）の軸対称取水の場合を議論する前に 2 次元取 水の場合を考える. 前述のようにこの場合はすでに著者 らは Oseen 近似に基づく解を得ているが，ここでは若 干手法を変えて 導出する. 式（21）で $1 / \xi$ のかかった 項を除くと次式を得る.

$$
\frac{\partial^{2}}{\partial \tau^{2}}\left\{\frac{\partial^{2}}{\partial \eta^{2}}+\frac{\partial^{2}}{\partial \xi^{2}}\right\} \varphi_{*}+\frac{\partial^{2} \varphi_{*}}{\partial \xi^{2}}=0 .
$$

この式は流れ関数 $\varphi_{*}$ をラグランジュの流れ関数とみな すと 2 次元取水の基本式となる. このときは捸動パラメ ーターとしての内部フルード数は $F_{r}=q T / d^{2}(q$ は単 位幅当りの流量) で定義されるものである. 次に式 (22) を直接解く前に $\partial^{2} / \partial \eta^{2} \gg \partial^{2} / \partial \xi^{2}$ の近似のもとに式 (23) の簡易化された方程式を考える.

$$
\frac{\partial^{4} \varphi_{*}}{\partial \tau^{2} \partial \eta^{2}}+\frac{\partial^{2} \varphi_{*}}{\partial \xi^{2}}=0
$$

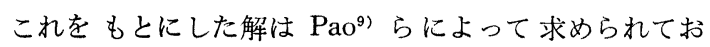
り,

$$
\begin{array}{r}
\varphi_{*}(\xi, \eta, \tau)=-2 \sum_{n=1}^{\infty} \frac{\cos n \pi b}{n \pi} \sin n \pi \eta \\
\cdot H\left[\tau-n \pi\left(\xi-\xi_{0}\right)\right] \cdots
\end{array}
$$

で与えられている，ところで, 式 (24) の非定常項は一 種の波動性を示しており， $\varphi_{*}$ をフーリエ変換した際に 現れる各モードはそれ自身固有の波速 $C_{n}=1 / n \pi$ をもっ て取水口より上流に遡上していることがわかり，あたか も開水路にみられる段波のようである. ところで貯水池 には取水口に向から平均流速 $U(=q / d)$ があり各波動 はこの平均流速と波との大小関係によって上流にそ上で きるか否かが決定される. $C_{n}$ を次元をもつ形で表わす と $d / n \pi T$ であるから上流にそ上し得るモード $(n)$ は $d / n \pi T>q / d$ を満たすものである. これを内部フルー ド数 $F_{r}$ によって示すと, $F_{r}=q T / d^{2}$ より,

$$
\frac{1}{n \pi}>F_{r}
$$

ここで, 式 (25) を満たす最大の整数を $N$ とすると, $n$ $=1$ から $N$ までのモードの波動のみが上流に遡上する ことになるが，ある点で観測していると $N$ モードまで の波動が全部通過した後はその観測点断面の流れは定常 となる.このときの解を準定常解とよぶと，これを $\varphi_{0}$ で表わして，

$$
\varphi_{0}=-r_{-}-2 \sum_{n=1}^{N} \frac{\cos n \pi b}{n \pi} \sin n \pi r_{i}
$$

となる. 式 (26) に より $\xi$ 方向の流速 $u$ を計算したものが 図一2 である。図よ り $F_{r}$ が小さくなる につれて流速分布は 鋭ってくるのがわか る.ところで式 (26) は $\xi$ に関係しない 解であるから取水口 上での境界条件を満 たしてはいない.こ の原因として $\xi$ 方向 の変化の大きい取水 口近くでは基礎方程

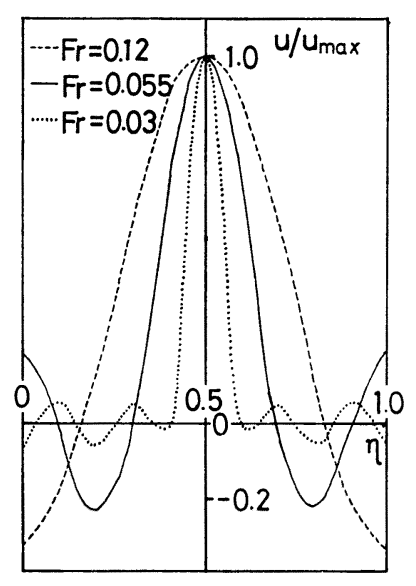

図一2 流速分布（式 (26)に上る) 式から移流項を無視することができない点にあると思わ れる.これに関して論文Iでは移流項を部分的に残した Oseen 近似に基づく解析を行っており，さらに粘性の 効果をも加えて式 (27) を得ている.

$$
\begin{aligned}
\varphi_{0}=-\eta-2 \sum_{n=1}^{N} \frac{\cos n \pi b}{n \pi} \sin n \pi \eta \exp \\
\quad\left[-(n \pi)^{3}\left(\xi-\xi_{0}\right) / 2 R_{e}\right] \\
-2 \sum_{n=N+1}^{\infty} \frac{\cos n \pi b}{n \pi} \sin n \pi \eta \exp \\
{\left[-n \pi\left(\xi-\xi_{0}\right) \sqrt{1-\left(n \pi F_{r}\right)^{-2}}\right] }
\end{aligned}
$$

ここに, $R_{e}$ は $d^{2} / \nu T$ で定義されるレイノルズ数であ る.

ところで式 (22) にもどり，この方程式に対し ク方 向のフーリエ展開, ラプラス変換一逆変換の操作を行う と次の解を得る.

$$
\begin{aligned}
& \varphi_{0}=-\eta-2 \sum_{n=1}^{\infty} \frac{\cos n \pi h)}{n \pi} \sin n \pi \eta \boldsymbol{S} \ldots \ldots \ldots \ldots(28) \\
& \boldsymbol{S}=\frac{1}{2 \pi i} \int_{r-i \infty}^{r+t \infty} \frac{e^{s t}}{s} \exp \left[-\frac{n \pi s}{\sqrt{1+s^{2}}}\left(\xi-\xi_{0}\right)\right] d s
\end{aligned}
$$

式 (28) 右辺の非定常項 $\boldsymbol{S}$ は式 (29) のようにラプ ラス逆変換の形で与えられるが，これを付録 1 に示す方 法により数值計算を行ったものが図一3,4 である。こ 


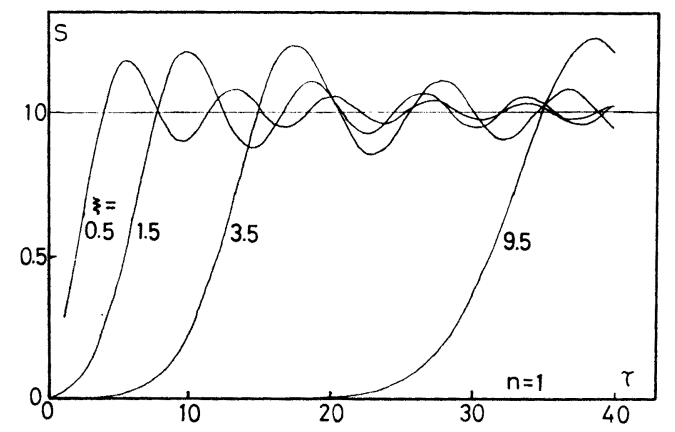

図-3 式 (29) $S$
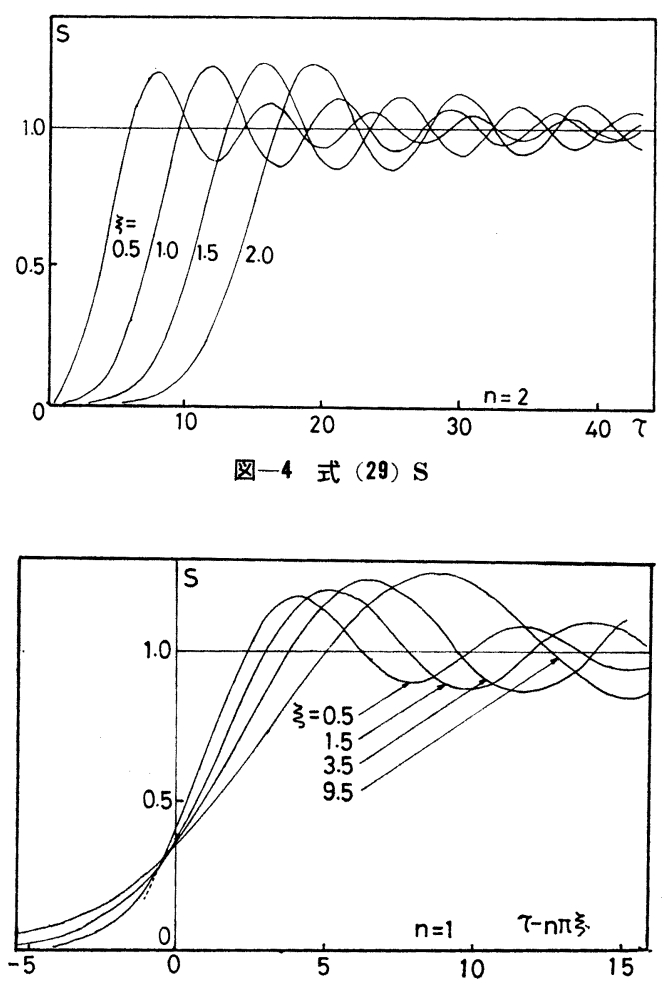

図-5 式 (29) S

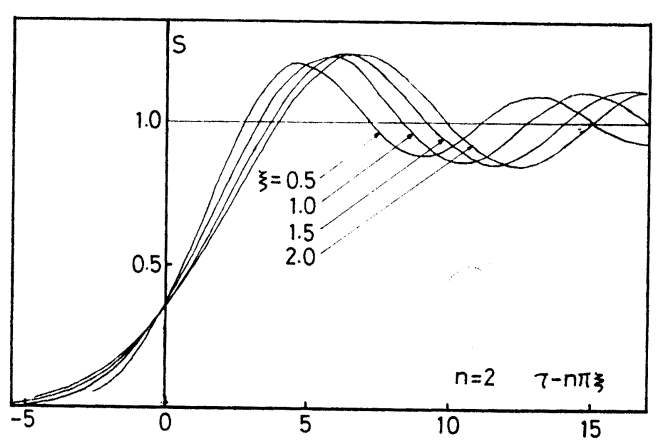

図-6 式 (29) S
れらの図より取水時に取水口より次々に伝播する波動を みることができる．また， $n$ が大きいほど伝播速度が小 さいことがわかり, 前述のように取水口に向かう断面平 均流速とこの波動の位相速度との大小により上流に遡上 することができない波動が存在することを考慮すると， 式 (28) 中の $\sum$ の は式 (26) と同様に $N$ に置き換 えられるべきである. 図一5, 6 は図-3,4 の横軸を $-n \pi \xi$ に変えて表示したものであり, これらの図からも 各モードの位相速度 $C_{n}$ は $1 / n \pi$ となることがわかる. また, 各モードともに時間が十分に経っと $S$ は 1 に収 束している. よって式 (28) において $\tau \rightarrow \infty$ としたと きは, 式 (26) と同じになり簡易化された方程式 (23)か ら求めた準定常解も, なんら省略しない式 (22) から求 めた準定常解もまったく同一になることがわかる.

\section{（6）軸対称選択取水}

次に式 (21) に基づく軸対称選択取水の理論解を導く. まず $\varphi_{*}$ を変数分離して次のようにおく.

$$
\left.\begin{array}{rl}
\varphi_{*} & =X(\tau, \xi) Y(\eta) \\
\cdot & =\partial / \partial \tau \\
\prime & =\partial / \partial \xi \\
\mathbf{v} & =\partial / \partial \eta
\end{array}\right\}
$$

このとき, 式 (21) は,

$$
\frac{\ddot{X}^{\prime \prime}}{\ddot{X}}-\frac{1}{\xi} \frac{\ddot{X}^{\prime}}{\ddot{X}}-\frac{1}{\xi} \frac{X^{\prime}}{\ddot{X}}+\frac{X^{\prime \prime}}{\ddot{X}}=-\frac{Y^{\bullet}}{Y} \cdots
$$

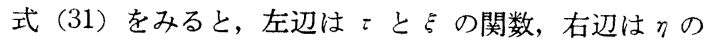
みの関数である.よって左辺 =右辺 $=a^{2}$ ( $a>0$ の定数 $)$ と置くと,

$$
\begin{aligned}
& Y^{\nabla v}+a^{2} Y=0 \ldots \ldots \ldots \ldots \ldots \ldots \ldots \ldots \\
& \ddot{X}^{\prime \prime}-1 / \xi \ddot{X}^{\prime}-1 / \xi X^{\prime}+X^{\prime \prime}=a^{2} \ddot{X}
\end{aligned}
$$

式 (32) の一般解は,

$$
Y=A \sin a \eta+B \cos a \eta
$$

境界条件を考慮すると $B=0, a=n \pi, n=1,2,3, \cdots$ と なることより，

$$
Y=\sum_{n=1}^{\infty} A_{n} \sin n \pi \eta
$$

一方，式 (33) を整理して,

$$
\begin{aligned}
\frac{\partial^{2}}{\partial \tau^{2}}\left\{\frac{\partial^{2} X}{\partial \xi^{2}}\right. & \left.-\frac{1}{\xi} \frac{\partial X}{\partial \xi}-a^{2} X\right\}-\frac{1}{\xi} \frac{\partial X}{\partial \xi} \\
& +\frac{\partial^{2} X}{\partial \xi^{2}}=0 \quad \ldots \ldots \ldots \ldots \ldots \ldots \ldots
\end{aligned}
$$

式（36）に対して付録 1 で定義されるラプラス 変換を 行うと, $\bar{X}(\xi, s)$ を $X(\xi, \tau)$ の像関数として,

$$
\frac{d^{2} \bar{X}}{d \xi^{2}}-\frac{1}{\xi} \frac{d \bar{X}}{d \xi}-\frac{a^{2} s^{2}}{1+s^{2}} \bar{X}=0
$$

式 (37) の一般解は,

$$
\bar{X}=\xi\left[C I_{1}\left(\frac{a s \xi}{\sqrt{1+s^{2}}}\right)+D K_{1}\left(\frac{a s \xi}{\sqrt{1+s^{2}}}\right)\right] \ldots
$$


ここに， $I_{1}, K_{1}$ はそれぞれオーダー 1 の第 1 種, 第 2 種 変形ベッセル関数 である. 式 $(38)$ で $\xi \rightarrow \infty$ での $\bar{X}$ の有界性の条件から $I_{1}$ は解として適当でないことより $C_{1}=0$ となる. このとき, 式 (35) を考慮して, $\varphi_{*}$ の ラプラス変換を $\bar{\varphi}_{*}$ とすると,

$$
\bar{\varphi}_{*}=\sum_{n=1}^{\infty} A_{n} \xi K_{1}\left(\frac{n \pi s \xi}{\sqrt{1+s^{2}}}\right) \sin n \pi \eta
$$

式 (39) の $A_{n}$ は $\xi=\xi_{0}$ 上での境界条件より決定され るものである. 式 (39) を便宜のため次のように置く と,

$$
\bar{\varphi}_{*}\left(\xi=\xi_{0}\right)=\sum_{n=1}^{\infty} E_{n} \sin n \pi \eta
$$

$\xi=\xi_{0}$ での境界条件より，

$$
\begin{gathered}
E_{n}=2 \int_{0}^{1} \bar{\varphi}_{*}\left(\xi_{0}\right) \sin n \pi \eta d \eta \\
\text { ここに } \bar{\varphi}_{*}\left(\xi_{0}\right)=\left\{\begin{array}{cc}
\eta / s & 0 \leq \eta \leq b, \quad \xi=\xi_{0} \\
(\eta-1) / s & b \leq \eta \leq 1, \quad \xi=\xi_{0}
\end{array}\right\}
\end{gathered}
$$

よって $E_{n}=-2 \cos n \pi b / n \pi s$ となる.

$$
\begin{gathered}
\text { ここで } E_{n}=A_{n} \xi_{0} K_{1}\left(n \pi s \xi_{0} / \sqrt{1+s^{2}}\right) \text { より, } \\
A_{n}=-\frac{2 \cos n \pi b}{n \pi s} \frac{1}{\xi_{0}} \frac{1}{K_{1}\left(\frac{n \pi s \xi_{0}}{\sqrt{1+s^{2}}}\right)}
\end{gathered}
$$

式（42）を式（39）に代人して,

$$
\bar{\varphi}_{*}=-2 \sum_{n=1}^{\infty} \frac{\cos n \pi b}{n \pi} \sin n \pi \eta\left(\frac{\xi}{\xi_{0}}\right) \frac{1}{s} \frac{K_{1}\left(\frac{n \pi \xi s}{\sqrt{1+s^{2}}}\right)}{K_{1}\left(\frac{n \pi \xi_{0} s}{\sqrt{1+s^{2}}}\right)}
$$

式 (43) をラプラス逆変換することにより $\varphi_{*}$ を得る が, これを $\varphi_{0}$ で表わすと，

$$
\begin{gathered}
\varphi_{0}=-\eta H(\tau)-2 \sum_{n=1}^{\infty} \frac{\cos n \pi b}{n \pi} \sin n \pi \eta \cdot S \ldots \\
\boldsymbol{S}=\frac{1}{2 \pi i} \int_{r-i \infty}^{r+i \infty} \frac{e^{s \tau}}{s}\left(\frac{\xi}{\xi_{0}}\right) \frac{K_{1}\left(\frac{n \pi \xi s}{\sqrt{1+s^{2}}}\right)}{K_{1}\left(\frac{n \pi \xi_{0} s}{\sqrt{1+s^{2}}}\right)} d s
\end{gathered}
$$

式（45）を解析的に積分するには通常は被積分関数の特 異点としての極を探し出し, 積分路を極を囲むように変 形して複素関数論における留数の定理を応用するのであ るが，式（45）の被積分関数の極に関して，その極を具 体的に知ること自体が 1 つの問題である.よってここで は以下に述べるようにラプラス逆変換の極限值定理を用 いて, (i) $\tau \rightarrow 0$ の場合, (ii) $\tau \rightarrow \infty$ の場合を求め, さ らに 付録 1 に示す数值計算により一般的に $S$ の挙動を 調べた.

(i ) $\tau \rightarrow 0$ : 取水開始直後

$$
\lim _{\tau \rightarrow 0} \varphi_{0}=-\eta-\lim _{s \rightarrow \infty} s \cdot \bar{\varphi}_{*}
$$

$$
\begin{aligned}
& =-\eta-2 \sum_{n=1}^{\infty} \frac{\cos n \pi b}{n \pi} \sin n \pi \eta \\
& \cdot\left(\frac{\xi}{\xi_{0}}\right) \frac{K_{1}(n \pi \xi)}{K_{1}\left(n \pi \xi_{0}\right)} \ldots \ldots \ldots \ldots \ldots . . .
\end{aligned}
$$

式（46）は軸対称取水の ポテンシャル 流れを表わす解 である。このように $H(\tau)$ の単位段階関数 (unit step function）で急に吸い込みが始まったときのいわば撃圧 力により始まる流れは，動き出し始めにおいて，密度成 層の有無にかかわらずポテンシャル流れが実現される. このことは粘性流体における Rayleigh 問題にみられる 現象と同様に，動き出し直後に抢いて流体は，粘性の効 果や成層の効果をあたかも忘れているかのごとく振舞っ ているようである ${ }^{12)}$.

(ii) $\tau \rightarrow \infty$ : 取水開始後十分に時間を経たとき

第 2 種の変形ベッセル関数の性質の 1 つとして, $\lim _{x \rightarrow 0} x K_{1}(x / a)=a$ があるが，これを用いると，

$$
\begin{aligned}
& \lim _{\tau \rightarrow \infty} \varphi_{0}=-\eta-\lim _{s \rightarrow 0} s \bar{\varphi}_{*} \\
& =-\eta-2 \sum_{n=1}^{\infty} \frac{\cos n \pi b}{n \pi} \sin n \pi \eta \\
& = \begin{cases}0 & 0 \leq \eta<b \\
1 & b<\eta \leq 1\end{cases}
\end{aligned}
$$

となる. 式 (47) は $\xi=\xi_{0}$ での境界条件と同じであり， 実際の現象とはかけ離れた解である。このような結果に 導いた原因は以下の解析により明らかとなる。

(iii) $\boldsymbol{S}$ の計算一ラプラス逆変換の数值計算

付録 1 に示寸計算方法に従って $\boldsymbol{S}$ を計算したものが 図一7,8 であり，横軸を時間 $\tau$, 縦軸を $\boldsymbol{S}\left(\xi_{0} / \xi\right)$ とし た， $n=1,2$ の場合の図である. これらの図より軸対称
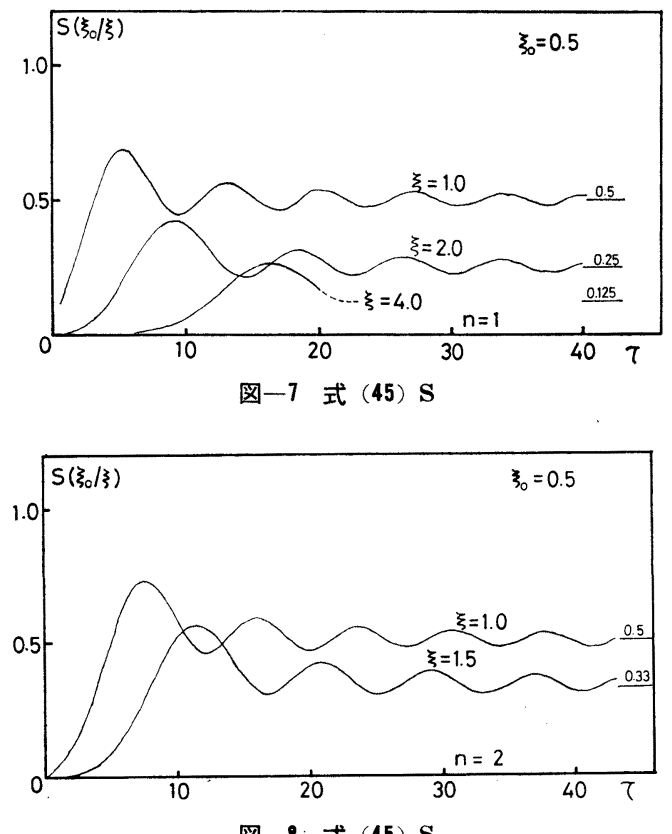

図一8 式 (45) $S$ 

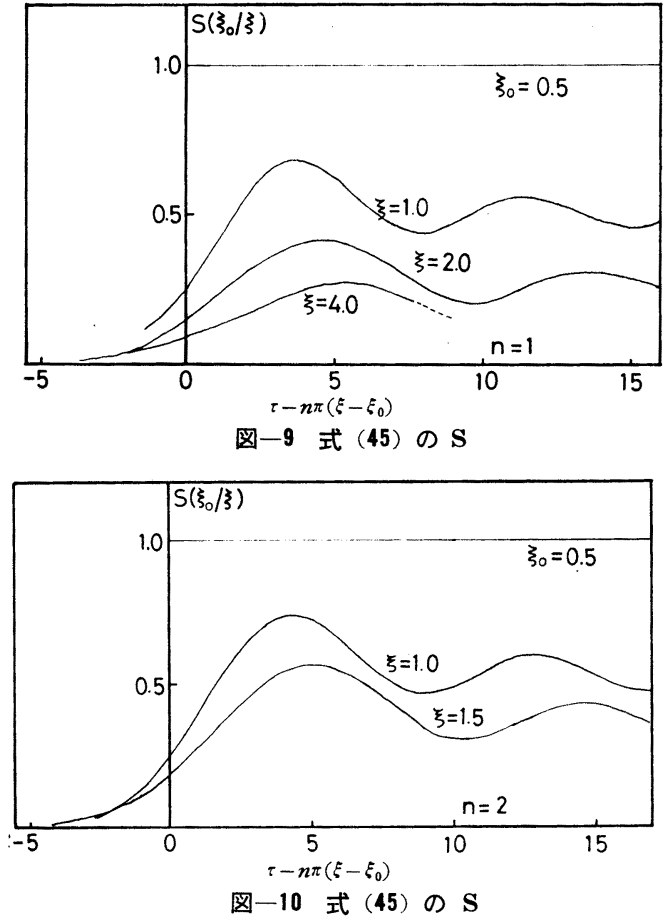

取水の解析解である式 (44) 中の非定常項 $\boldsymbol{S}$ もある種 の波動性を示しており，この波動は 2 次元取水の場合の 図一3,4 においてみられたものと同じものと考えられ る. 2 次元取水と軸対称取水に現れるこの波動は密度成 層流体中に存在するモード波の一種であると考えられる が， $\xi$ 方向の波数をもたないことより段波とみることも できる．ところで軸対称の場合はこの波動の位相速度を 明確に 表わすことができないが，2 次元取水の場合の $C_{n}=1 / n \pi$ によって 図一7,8 整理しなおすと 図一9, 10 になる。 これらの図より軸対称取水の場合の波動も 近似的には 2 次元の場合の波動と同じ位相速度をもつこ とがわかる.このことは表面波における Cauchy-Poisson 波に打いて 2 次元と軸対称の波を考えたときに，ほぼ同 じ位相速度をもっていることと類似であろう。ところで 軸対称取水においては, 取水口に向から平均流速のうち 最大值は $\xi=\xi_{0}$ において生じており， $Q_{0} / 2 \pi r_{0} d$ である が， 2 次元取水における議論と同様に $C_{n}=1 / n \pi(=d$ $n \pi T)$ の位相速度との大小によって上流に遡上し得るモ 一ドと遡上することのできないモードが存在することが わかる. つまり $d / n \pi T>Q_{0} / 2 \pi r_{0} d$ を満たすモード （n）のみが上流に遡上することになる．この関係を取水 パラメーター $G$ によって示すと,

$$
\frac{1}{n \pi}>\frac{G}{\xi_{0}}
$$

となる. 式（48）を満たす $n$ のうち最大の正整数を $N$ とすると, 軸対称取水の非粘性定常解は式 (26) となり,
形式上 2 次元取水と軸対称取水の準定常解は同一のもの になる. ただし， 2 次元取水の流れ関数はラグランジュ の流れ関数であり，軸対称の場合はストークスの流れ関 数であることは前記のとおりである．ところで式 (26) は既述のように取水塔上での境界条件を満たしていない が，2次元取水の場合は論文Ｉに示したようにOseen 近似に基づく基礎方程式を用いることによりこの問題を 解決している。，一方，軸対称取水の場合は Oseen 近似 を用いることはできない，しかし，2 次元取水の準定常 解である式(27) の右辺第 3 項は $\xi$ が大きくなると急速に 減衰する関数であるから，流れの大部分に扔いては非粘 性解として式（26）を用いることができる．このことは 軸対称取水に関しても同様に成り立つことが予想され る.つまりたとえ取水塔上での境界条件を満たすように 新たに項を付加してもその項も $\xi$ が大きいところでは 急速に減衰する関数となろう。よって流れの関数の違い

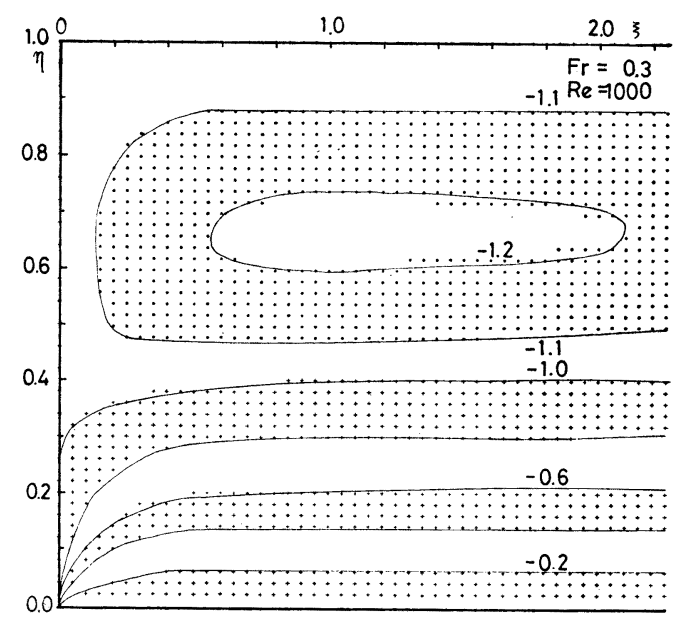

図一11 流 線 図

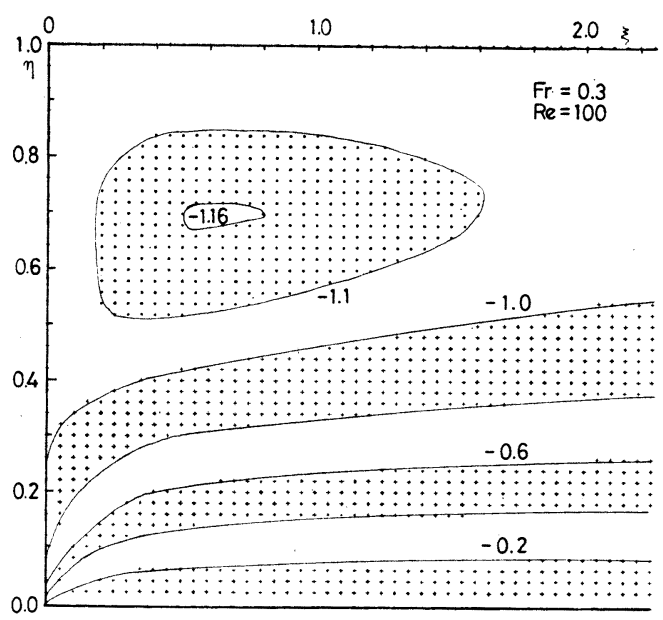

図一12 流 線 図 


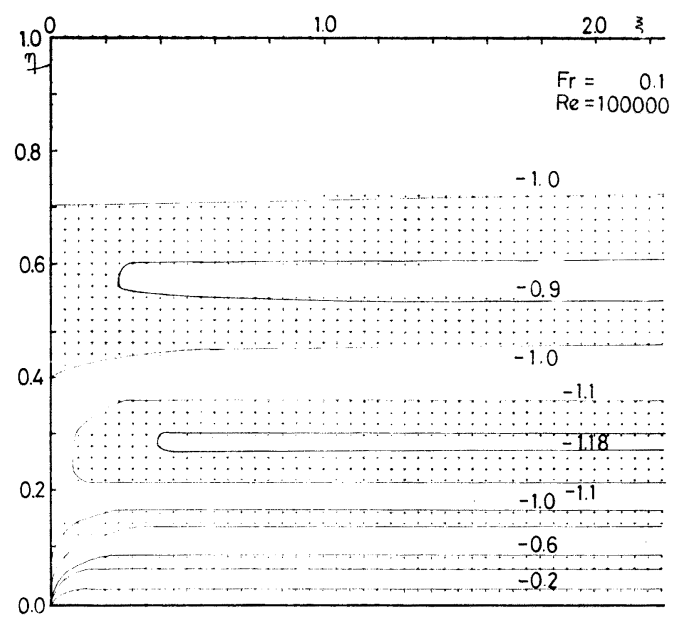

図一13 流 線 図

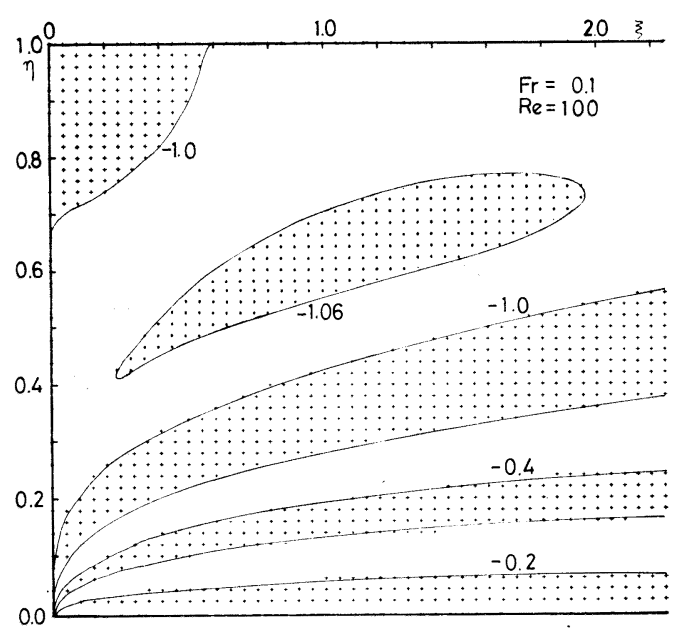

図-14 流 線 図

を考慮に入れるならば式 (27) は 2 次元選択取水の準定 常解であるとともに, 取水塔を離れた $\xi$ の大きいとこ ろでの軸対称取水の準定常解でもある.

図一11〜14 は, 式 (27) に基づき, $F_{r}, R_{e}$ をパラメ 一ターとして表わした 流線図である.これらの図より $F_{r}$ が小さくなるにつれて取水される幅は狭くなること がわかる.これは $F_{r}$ が小さいと, 式 (25), あるいは 式（48）よりわかるように上流に遡上するモードが多く なり, 加え合わせるモードが多くなればなるほど取水幅 は狭くなるからである. また, 同じ $F_{r}$ に対しては $R_{e}$ が小さいほど, 取水幅は広くなることがわかる.これは 式 (27) からわかるように $R_{e}$ が小さいほど高モードの 波動は減衰し, はじめの数モードによって流れが決まっ てしまうからである.これらのことは定性的には以下に 述べる実験結果とよく一致するものである.

\section{4. 実験装置および実験結果}

上述の解析結果の妥当性を検討するために以下のよう な実験を行った. 本論文の解析結果では 2 次元取水と軸 対称取水の等価性が明らかになっているので, 実験とし ては 2 次元取水の場合を取り扱った.

\section{（1）実験装置および実験方法}

図-17 が本実験で用いた水槽で，幅 $9 \mathrm{~cm} \times$ 高さ 19 $\mathrm{cm} \times$ 長さ $100 \mathrm{~cm}$ のアクリル製である. また， 2 次元取 水を実験するために 水槽の一方の壁に 底から $10 \mathrm{~cm}$ の 高さに $0.2 \times 9 \mathrm{~cm}$ のスリットを設けている. また，取 水中の自由表面の低下に伴う流量の変化を防ぐために水 槽の他端に $19 \times 60 \times 60 \mathrm{~cm}$ の補助水槽を設けている. 本研究の理論で取り扱った直線状の密度成層を作るため

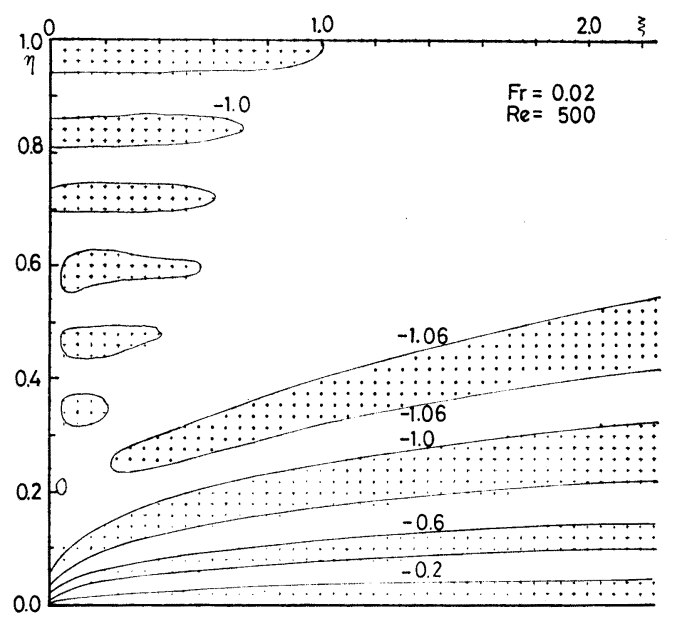

図一15 流 線 図

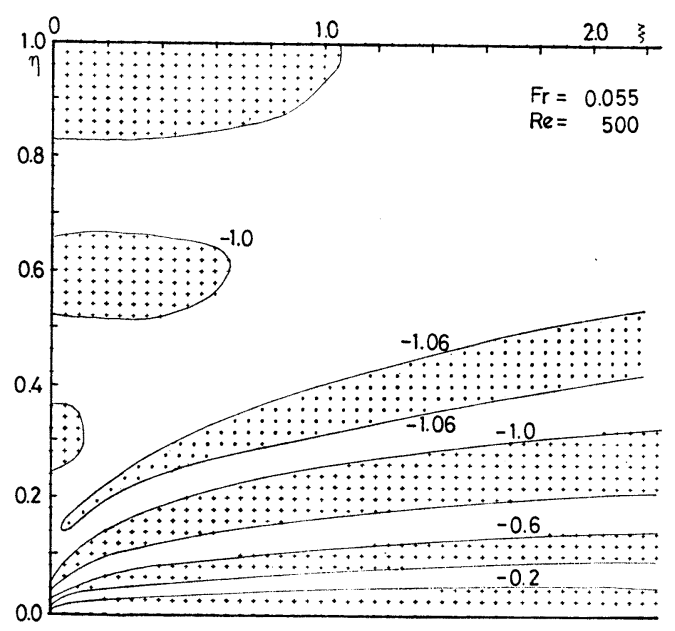

図一16 流 線 図 


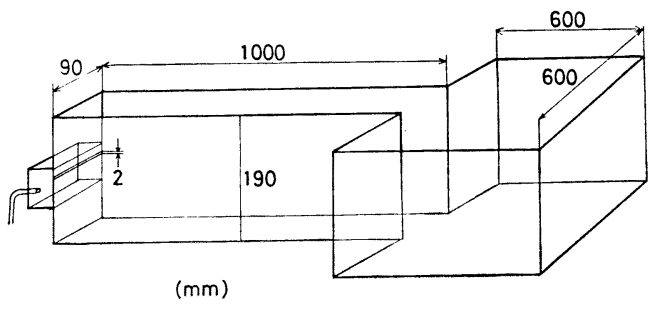

図一17実 験 装

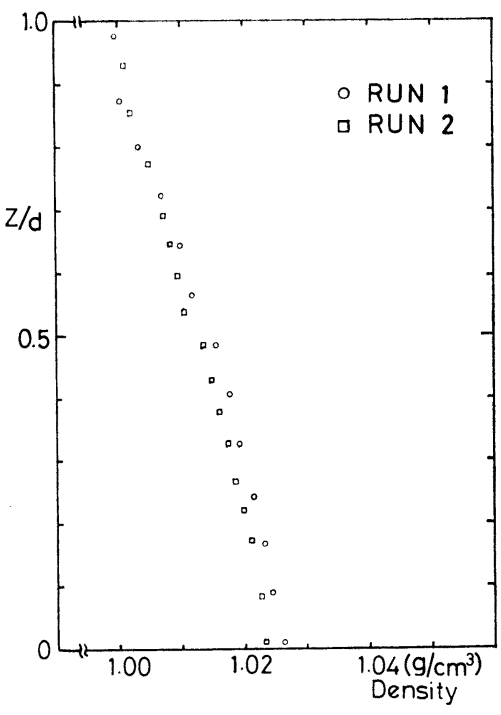

図-18 密度分 布

に濃度（密度）をあらかじめ測定した食塩水をサイフォ ンにより静かに水槽内に入れ, 入れ終わった後に水槽内 の水をもう一度若干量採水し, この濃度 (密度) を測定 することにより密度分布を知った．図一18 がこのよう にして作った密度分布である. さらに水槽端に取り付け たビニールホースの先端位置を適当な高さに固定し, こ の流量をメスシリンダーによって測り，単位幅当りの流 量を算定した. 取水開始後の流速測定にはトレーサー法 を用いて抢り，n-ヘキサン（比重 0.678）とモノクロー ルベンゼン（比重 1.107）を適当に混合させることによ って任意の密度をもった液を作り, さらにオイルレッド を適量混ぜることにより赤色に着色し，取水を始める前 に静置した水槽内にこの液をピペットによって押し出 し，このときできる赤色の小滴の移動を $35 \mathrm{~mm}$ カメラ と $8 \mathrm{~mm}$ カメラによって追跡し, その移動距離から流

表一1 実 験 諸

\begin{tabular}{c|c|c|c|c|c}
\hline & $\begin{array}{c}q \\
\left(\frac{\mathrm{cm}^{2}}{\mathrm{sec}}\right)\end{array}$ & $\begin{array}{c}\varepsilon \\
(1 / \mathrm{cm})\end{array}$ & $\begin{array}{c}T \\
(\mathrm{sec})\end{array}$ & $\begin{array}{c}F_{r} \\
\left(\frac{U T}{d}\right)\end{array}$ & $\begin{array}{c}R_{e} \\
\left(\frac{d^{2}}{\nu T}\right)\end{array}$ \\
\hline RUN 1 & 9.13 & $1.36 \times 10^{-3}$ & 0.866 & $2.19 \times 10^{-2}$ & $4.15 \times 10^{4}$ \\
RUN 2 & 4.83 & $1.32 \times 10^{-3}$ & 0.879 & $1.18 \times 10^{-2}$ & $4.11 \times 10^{4}$ \\
\hline
\end{tabular}

速を算出した。

\section{（2）実験結果}

本論文では, おもに内部フルード数 $F_{r}$ を変えて行っ た実験のうち, 特に流速分布を密に測定した 2 ケースを 揭げている．表一1 に実験諸量を載せている，Run 1 と Run 2 のおもな相違は内部フルード数がそれぞれ 0.0219 と 0.0118 の約 2 倍異なっている点である. 図 -19 は取水開始直後からほぼ定常状態に達するまでの Run 2 の水槽内全域にわたる 流速分布の変化を示すも のである. この図より取水開始直後 $t=0.7$ 秒では水槽 全体の流速分布は鉛直方向にほぼ一様であり, ポテンシ
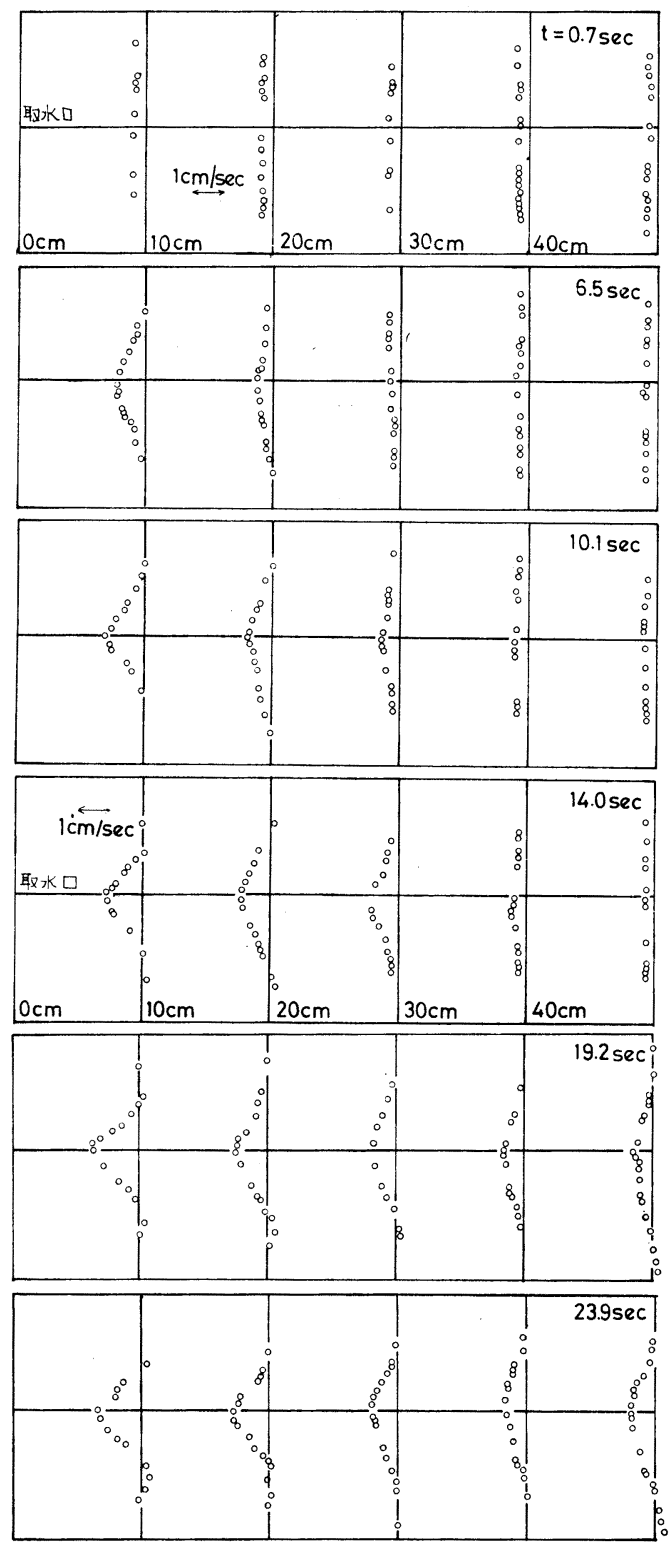

図一19 流速 分 布 
ヤル流れが現れているのをみることができる.これは論 文Iにおいて予測し，軸対称取水の場合も本文式 (46) で示したものである. ところで無次元化された取水口高 さbはほぼ 0.5 であるから式 (26) あるいは式 (27) 中 の $\cos n \pi b$ は $n$ が奇数で $0, n$ が偶数で $(-1)^{n / 2}$ であ る. よって取水中に見い出すことのできる第 1 モードは $n=2$ である. 一方, 理論から $n=2$ のモードの位相速度 は $C_{2}=d / 2 \pi T$ であり, 取水口に向から平均流速 $(q / d)$ を考虑に入れると実際の第 1 モードの伝播速度 $C$ は, $C$ $=C_{2}-q / d$ と表わすことができる. よって取水口より 10, 20, 40, $50 \mathrm{~cm}$ 離れた各点において第 1 モードが現わ れる時刻はそれぞれ $3.8,7.5,11.3,15.1,18.8$ 秒とな る. 図一18 で $t=6.5,10.1,14.0,19.2,26.2$ 秒のそ れぞれ $10,20,30,40,50 \mathrm{~cm}$ の地点の流速分布をみる と確かに一様流速ではなく, ある分布形を持ったモード がすでに到達しているのをみることができる，このモー ドの伝播現象をより詳細にみるために各点各時刻の流速 分布のらち縦軸を $\eta=b$ 上の流速, 横軸を $t-x / C(C$ は上述の第 1 モードの伝播速度）として表示したものが 図一20 と図一21である.これらの図の意味するところ

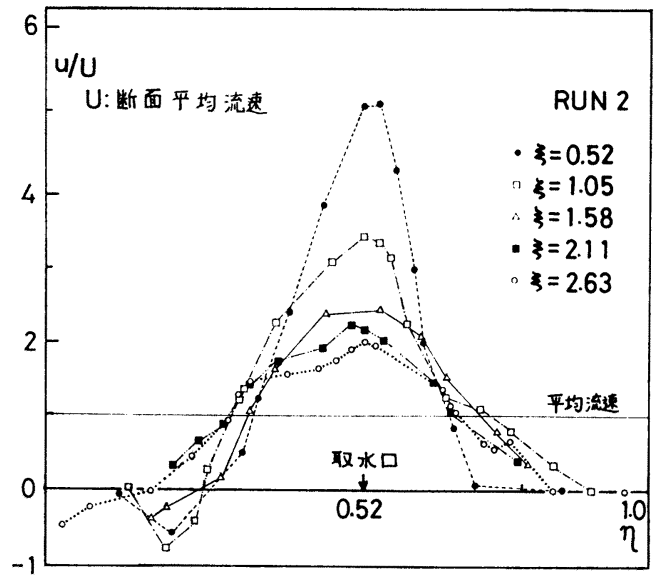

図一22 定常状態の流速分布

は結局 図一6〜8 と同じである. また, $t$ が十分大きく なっても縦軸の速度が増大しつづけているのは, 次々と 到達するモードによって流速分布が次第に細く鋭ってく るからであろう。

次に取水開始後十分に時間を経て定常な流れになった と思われる時刻での Run 2 の 流速分布が 図一22 に示されて いる.この流速分布が上下（左 右）非対称なのは取水口高さが 完全に水深の半分でないこと, 取水前の密度分布が完全に值線 でないこと，底面付近の粘性の 効果, さらに実験に用いた水槽 の有限性等の原因が考えられる から上記の理論結果と得られた

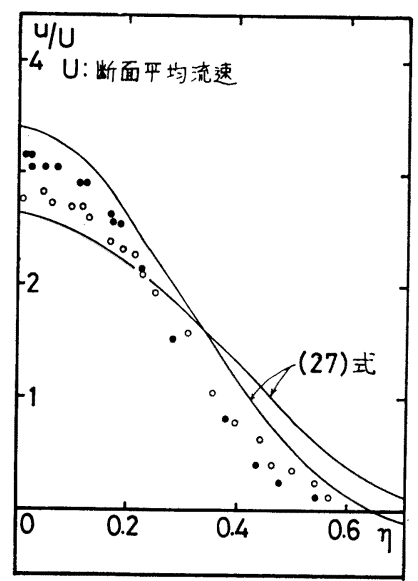

図一23定常状態の流速分布

(Kao \& Pao ら ${ }^{10)}$ による実験から. $F_{r}(=U T / d)=500, \bigcirc: \xi=1, \bigcirc:$ $\xi=2$, 一は式 (27) で $R_{e}=500$ とし て計算したもの) 


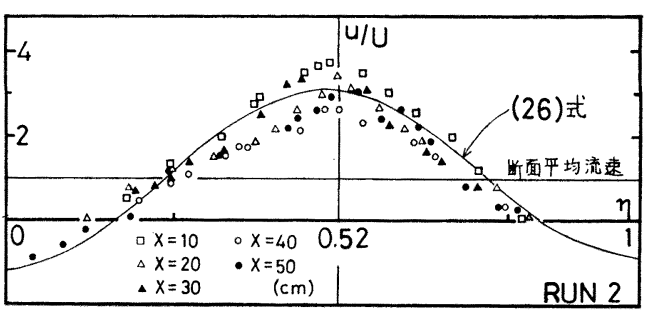

図一24 $n=2$ までの流速分布

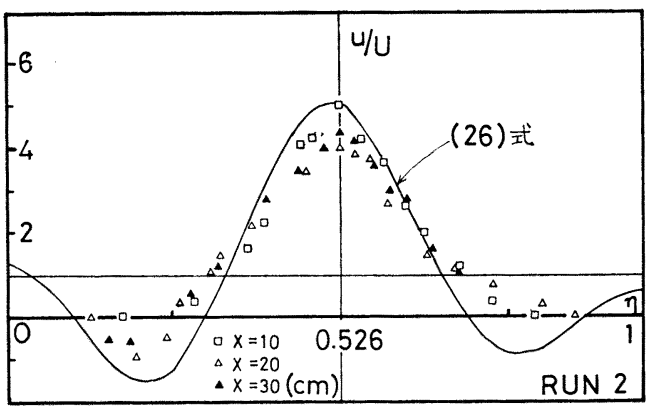

図一25 n=4 までの流速分布

実験結果とを早急に比較することは困難ではあるが， Run 2 の内部フルード数 $F_{r}$ とレイノルズ数 $R_{e}$ を用 いて式（27）から流速分布の計算を試みた. その結果, 図一2 の $F_{r}=0.03$ の場合の流速分布似似て非常に鋭 った分布形状をもち，図一22 のような形をしていない ことがわかる.

ところで図一23 は Kao and Paoら ${ }^{10)}$ が行った同様 の実験とレイノルズ数 $=500$ として式 (27) より計算し た流速分布との比較を示している. この場合は計算に用 いたレイノルズ数は $d^{2} / \nu T$ のレイノルズ数の数百分の 1であり, 式(27)からわかるように粘性の効果をより大 きく見積り，高モードからの寄与を抑えていることにな る.このことをより詳細に調べてみるために第 1 モード $(n=2)$ だけが各点を通過しているときの流速分布を 図 -24に, 第 2 モード $(n=4)$ までのモードが通過して いるときの流速分布を 図一25に示し，これらと全モ一 ドが出そろった場合としての 図一22 と比較してみる.

図一24,25 中の実線は $F_{r}, R_{e}\left(=d^{2} / \nu T\right)$ ともに実験值 を用い，式 (27) より計算したものであるが，図一24よ り単一モードのみが進行している場合は本研究（論文 I を含め) で行った線形理論解析が十分に適用し得ること がわかる。しかし，図一22,25 のようにモードが出揃う につれて上記の線形解からはずれてくる. 前述のより小 さいレイノルズ数を用いた方が実験との適合性がよくな ることや, 各モードの単純な重ね合せがきかないことか ら判断して, 選択取水の問題の取り扱いに扔いては, モ 一ドの伝播という事実のほかに各モード間における非線 形の干渉を考慮しなければならないことを示唆している
ように思われ，今後はこの方面の研究をしていくつもり である。

\section{6. 結 論}

本研究で得られたこと以下に列挙する.

（1） 2 次元選択取水に批いて Pao ら ${ }^{9)}$ や McEwan

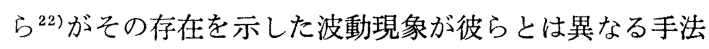
一ラプラス逆変換の数值計算一を用いて明らかにされ 2 次元取水の実験において確認された.

（2）軸対称選択取水においても同じ手法を用いるこ とにより 2 次元取水の場合に現れた波動と同様の現象が 見い出され，この位相速度は 2 次元の場合の位相速度 $1 / n \pi$ に近似的に等しいことがわかった.

（3）取水を開始すると，位相速度の異なった各モー ドが取水口に向から平均流速にさからい，上流に遡上し てくる. 遡上し得るすべてのモードが出そろうと, 以後 は定常な流れになる。

（4）流れ関数の違いを考慮すると，2次元選択取水 と軸対称選択取水の流線は取水口近傍を除いて近似的に 等しい.

（5）軸対称取水においてよどみ層の発生条件は式 (48) より内部フルード数 $(G)$ とともに取水塔半径に よって決定される，2次元取水の場合は式（25）により 内部フルード数のみにより決定される.

（6）従来の研究では取水口を離れた上流で一様流速 になるといった無限上流での境界条件を破壊する解が得 られていたが, 本研究により, その原因が解明され, 定 性的には, 現実に生じている選択取水の流れの状況を示 すことができた.

（7）選択取水の定量的な把握には非線形の領域まで 解析を進め㸚ばならない。

\section{付録 1 逆ラプラス変換の数值計算}

ラプラス変換, 逆変換は (S 1), (S 2) で定義される.

$$
\begin{aligned}
& F(p)=\int_{0}^{\infty} e^{-t p} f(t) d t \cdots \cdots \cdots \cdots \cdots \cdots \cdots . . . \\
& f(t)=\frac{1}{2 \pi i} \int_{r-i \infty}^{r+i \infty} e^{p t} F(p) d p \cdots R[p]>r
\end{aligned}
$$

ここに, $r$ は $R[p] \geq r$ で $F(p)$ が正則となる実数. 次に $p=r+i \sigma$ とおくと式 (S2) は,

$$
f(t)=\frac{e^{r t}}{2 \pi} \int_{-\infty}^{\infty} e^{i \sigma t} F(r+i \sigma) d \sigma \cdots
$$

となる. 式 (S 3 ) は複素関数 $F(p)$ の複素フーリエ変 換と考えられるからコンピューターライブラリーを使用 することによりラプラス逆変換の数值計算を行うことが できる. 本論文では文献 23) の手法を参考にして以下 
のように行った. $f(t) e^{-r t}=g(t), F(c+i \sigma)=G(\sigma)$ と 置くと式 (S3) は,

$$
g(t)=\frac{1}{2 \pi} \int_{-\infty}^{\infty} e^{i \sigma t} G(\sigma) d \sigma
$$

このとき式 $(\mathrm{S} 1)$ は,

$$
\begin{aligned}
& F(p)=G(\sigma)=\int_{0}^{\infty} e^{-(r+i \sigma) t} g(t) e^{r t} d t \\
& =\int_{0}^{\infty} e^{-i \sigma t} g(t) d t
\end{aligned}
$$

式 (S 2) と式 (S 5) をみると, $f(t)$ と $F(p)$ に関す るラプラス変換は $g(t)$ と $G(\sigma)$ のフーリエ変換と考え ることができる.

次に $g(t)$ が $0<t<T$ で有限で $t>T$ で negligible small かあるいは $T$ が十分に大きいとき, $g(t)$ を $(0, T)$ でフーリエ級数に展開する.

$$
\left.\begin{array}{l}
g(t)=\sum_{k=-\infty}^{\infty} C_{k} e^{i k \omega t} \\
\omega=2 \pi / T
\end{array}\right\}
$$

ここに, $C_{k}$ は上記の条件のもとで，

$$
\begin{aligned}
& C_{k}=\frac{\omega}{2 \pi} \int_{0}^{T} g(t) e^{-i k \omega t} d t \fallingdotseq \frac{\omega}{2 \pi} \int_{0}^{\infty} g(t) e^{-i k \omega t} d t \\
& =\frac{\omega}{2 \pi} G(k \omega)
\end{aligned}
$$

式（S7）を式（S6）に代入して,

$$
\begin{aligned}
g(t)= & \frac{\omega}{2 \pi}\left\{G(0)+\sum_{k=1}^{\infty}\left[G(k \omega) e^{i k \omega t}\right.\right. \\
& \left.\left.+G(-k \omega) e^{-i k \omega t}\right]\right\} \quad \ldots \ldots \ldots \ldots . . .
\end{aligned}
$$

さらに式 (S 8) を実部と虚部に分けて,

$$
G( \pm k \omega)=F(r \pm i k \omega)=A(k \omega) \pm i B(k \omega)
$$

このとき，式（S 8) は式（S10）となる.

$$
\begin{aligned}
& g(t)=\frac{\omega}{\pi}\left\{\frac{A(0)}{2}+\sum_{k=1}^{\infty}[A(k \omega) \cos k \omega t\right. \\
& -B(k \omega) \sin k \omega t]\}
\end{aligned}
$$

ここで, $f(t)=g(t) e^{r t}$ の関係を用いることにより像関 数 $F(p)$ のラプラス逆変換は式 (S 10) の計算に帰着す る.ところで式 (S 10) の計算では Filon の方法を用い ることにより解の精度の向上を図ることができる ${ }^{17)}$. 図 -26 は $F(p)=1 / p$ の場合 (A) と $F(p)=p / \sqrt{1+p^{2}}$ の場合 $(\mathrm{B})$ の計算例で，これらの逆変換はそれぞれ単 位段階関数と第 0 次のベッセル関数 $J_{0}(z)$ になるもの である. 図中（A）は上記の手法によって計算されたも のであり, $t=0$ 近くの立上がりに Gibbs 現象が現われ ている.（B）は実線が厳密解, ・印が計算值である.と もに $t=0$ 近くを除けば十分な精度をもっていることが わかる. なお (A),(B) ともに $T=1000$ で計算してい る. この計算手法とは異なる 方法が文献 18), 23) に示

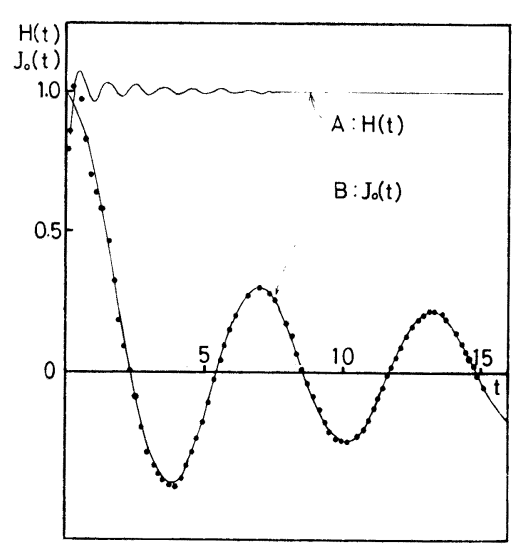

図一26 ラプラス逆変換の数值計算例

されており，ともにフーリエ積分の収束を早め，精度を 上げる技法が図られている.

\section{付録 2}

オーダー 1 の第 2 種変形ベッセル関数 (変数が複素数 の場合を含む） $K_{1}(z)$ の計算は参考文献 19）により次 式で計算する.

$$
\begin{aligned}
0<|z| \leq & 2 \\
z K_{1}(z)= & z I_{n}(z / 2) I_{1}(z)+1+0.15443144(z / 2)^{2} \\
& -0.67278579(z / 2)^{4}-0.18156897(z / 2)^{6} \\
& -0.01919402(z / 2)^{8}-0.00110404(z / 2)^{10} \\
& -0.00004686(z / 2)^{12} \ldots \ldots \ldots \ldots \cdots \cdots(\mathrm{S} 11) \\
2 \leq|z|< & \infty \\
z^{1 / 2} e^{z} & K_{1}(z)=1.25331414+0.23498619(2 / x) \\
& -0.03655620(2 / x)^{2}+0.01504268(2 / x)^{3} \\
& -0.00780353(2 / x)^{4}+0.00325614(2 / x)^{5} \\
& -0.00068245(2 / x)^{6} \cdots \cdots \cdots \cdots \cdots \cdots \cdots(\mathrm{S} 12)
\end{aligned}
$$

また, 式 (S 11) 中のオーダー1の第 1 種変形ベッセル 関数は次式により計算する.

$0<|z|<3.75, t=z / 3.75$

$$
\begin{aligned}
& z^{-1} I_{1}(z)=0.5+0.87890594 t^{2}+0.51498869 t^{4} \\
& \quad+0.15084934 t^{6}+0.02658733 t^{8} \\
& \quad+0.00301532 t^{10}+0.00032411 t^{12} \cdots(\text { S } 13)
\end{aligned}
$$$$
\text { 参考文 献 }
$$

1) 水理公式集 (昭和 46 年改訂版), 土木学会編.

2) Debler, W.W. : Stratified flow into a line sink, J. Eng. Mech. Div., Proc. A.S.C.E. 85, 1959.

3）吉川秀夫 - 山本晃一: 䝪水池の水の挙動に関する研究, 土木学会論文報告集, 186 号, 1971 年 2 月.

4) Yih, C.S. : Dynamics Dynamics of Non-homogeneous Fluids, Macmillan Camp., 1965.

5) Trustrum, K. : Rotating and stratified flow, J. Fluid Mech., 1964.

6) Kao, T.W. : A free-streamline solution for flow into a line sink, J. Fluid Mech. Vol. 21, part 3, 1965. 
7) Kao, T.W. : Free-streamline theory for inviscid stratified flow into a line sink, Phys. Fluid, 13, 1970.

8) Kao, T.W., Pao, H.P. and Wei, S.N. : Time dependent behavior of stratified flow in a channel towards a line sink, Int. Symp. Stratified Flow, IAHR, Novosibirsk, 1972.

9) Pao, H.P. and Kao, T.W. : Dynamics of establishment of selective withdrawal from a line sink, Part 1, Theory, J. Fluid Mech. 65, 1974.

10) Kaot T.W., Pao, H.P. and Wei, S.N. : Dynamics of selective withdrawal from a line sink, Part 2, Experiment, J. Fluid Mech. 65, 1974.

11) Koh, R.C.Y. : Viscous stratified flow towards a sink, J. Fluid Mech. 24, 1966.

12) Koh, R.C.Y. : Unsteady stratified flow into a sink, J. Hydraulic Res. 4, 1966.

13) Imberger, J. : Two-dimensional sink flow of a stratified fluid contained in a duct, J. Fluid Mech. 53, 1972.

14）日野幹雄-大西外明: Point sink 一の密度成層流の解析, 東京工業大学, 土木工学科研究報告 No. 5, 1968.

15）大西外明・日野幹雄：樑層取水一の考察（II）, 第 15 回海 墜工学講演会講演集, 1968 .

16）日野幹雄・大西外明：密度成層流におよぼす Point sink
の高さの効果, 土木学会論文報告集, 第 163 号, 1969 年 3 月.

17）日野幹雄：スペクトル解析, 朝倉書店, 1977.

18）台丸谷政志. 内藤正鄰：熱衝撃を 受ける半無限体の過渡 的挙動の解析, 日本機械学会論文集 (第 I 部), 39 巻 318 号, 1973 年 2 月.

19) Abramowitz, M. and Stegun, I.A. (eds.) : Handbook of Mathematical Functions with Formulas, Graphs and Mathematical Tables, Dover Publ. Inc., New York, 1972.

20）石橋 毅 - 秋元 保 - 白砂孝夫 - 石川晴雄 - 斎藤 茂 宮永洋一: 成層型貯水池内の流れと熱収支の現地観測, 第 21 回水理講演会論文集, 1977.

21）吉川秀夫・山田 正・水谷俊孝: 非定常選択取水に関す る研究, 第 22 回水理講演会論文集 (論文 I ), 1978.

22) McEwan, A.D., Baines, P.G. : Shear fronts and an experimental stratified shear flow, J. Fluid Mech. Vol. 63, Part 2, 1974.

23) Krylov, V.I., Skoblya, N.S. : Numerical Inversion of Laplace Transforms, Translated from Russian by D. Louvish, Israel Programming for Scientific Translations, Jerusalem, 1969.

(1977.12.20 • 受付) 